\title{
Certified Nurse Assistant
}

National Cancer Institute

\section{Source}

National Cancer Institute. Certified Nurse Assistant. NCI Thesaurus. Code C71310.

A person who has completed a brief health-care training program, and who provides

support services for RNs and LPNs. Also known as an orderly or, when certified by a state agency, a certified nurse assistant. 